\title{
Nomenclatural notes on the taxonomy of some Indian and Chinese orchids
}

\author{
A. Nageswara Rao \\ 1-156, Raja Rajeswari Nagar, Eluru-534 005, West Godavari district, Andhra Pradesh \\ E-mail: dr_anrao@rediffmail.com
}

[Received 18.11.2020; Revised 07.12.2020; Accepted 18.12.2020; Published 31.12.2020]

\begin{abstract}
Two orchid species viz. Coelogyne ghatakii T.K.Paul, S.K.Basu \& M.C.Biswas and Cylindrolobus motuoensis X.H.Jin \& J.D.Ya are reduced to new synonyms. Two more species viz. Cleisostoma parishii (J.D.Hooker) L.A.Garay and Seidenfadeniella salimii J.Mathew, Hrideek, V.B.Sreekumar \& K.Madhusudhanan are transferred to the genera Sarcoglyphis L.A.Garay and Cleisostomopsis Seidenfaden respectively.
\end{abstract}

Keywords: orchid species, new synonyms, Sarcoghphis, Cleisostomopsis

\section{INTRODUCTION}

During the course of critical study on orchid flora of India, based on the comparative study of protologues, type specimens, detailed descriptions with analytical drawings and photos, some of the orchid species are found either conspecific with already described species or required generic transfers due to their salient features. All these species are enumerated below with notes of critical observations.

1. Coelogyne ghatakii T.K.Paul, S.K.Basu \& M.C.Biswas in J. Bombay Nat. Hist. Soc. 86: 425 1989 (publ. 1990)

While describing this species as new from Manipur (Paul et al. 1989), considering the character of inflorescence with flowers which mostly open successively, only one or a few at a time, the authors have compared it with the species Coelogyne griffithii J.D.Hooker of the section Ancipites E.H.Pfitzer \& F.Kraenzlin (1907). However, in the present study, it is found that $C$. ghatakii is agreeing in all vegetative and floral features with C. prolifera Lindley (Table 1) of the section Proliferae Lindley (1854), sensu stricto where generally flowers in the inflorescence open all at a time.

Table 1. Similarities between Coelogyne ghatakii and C. prolifera

\begin{tabular}{|l|l|l|}
\hline Character & \multicolumn{1}{|c|}{ C. ghatakii } & \multicolumn{1}{c|}{ C. prolifera } \\
\hline Leaf & $10-15 \times 2.5-3.0 \mathrm{~cm}$ & $9.0-16.5 \times 1.5-2.8 \mathrm{~cm}$ \\
\hline Inflorescence & $12-14 \mathrm{~cm}$ long, 6-8 flowered & $\begin{array}{l}\text { 6-22 cm long (elongating every year upto } 6 \\
\text { times), 5-11 flowered }\end{array}$ \\
\hline Flowers & $1.0-1.5 \mathrm{~cm}$ across, greenish yellow & $1.0-1.3 \mathrm{~cm}$ across, greenish yellow \\
\hline Sepals & $0.6-0.7 \times 3.0 \mathrm{~cm}, 3$-nerved & $0.6-0.8 \times 0.3-0.4 \mathrm{~cm}, ? ? ? ?-$ nerved \\
\hline Petals & 6-7 x $0.5 \mathrm{~mm}$ & $0.6-0.8 \times 0.05 \mathrm{~cm}$ \\
\hline Labellum & Lateral lobes ovate-oblong, 2 keels on disc & Lateral lobes oblong, obtuse, 2 keels on disc \\
\hline Flowering time & April-June & May-June \\
\hline
\end{tabular}

The sectional delineating character i.e. flowers in the inflorescence open all at a time or successively, cannot be considered always as a strict parameter because there are some instances where the author has noticed the inflorescences with few buds and opened flowers in the wild populations 
of species C. longipes, C. prolifera, C. schultesi of the section Proliferae. Hence, considering this character as exceptional, since $C$. ghatakii is similar to $C$. prolifera in remaining all important characters as indicated in Table.1, both the species are proved conspecific. Accordingly, $C$. ghatakii has been reduced here as a new synonym to the latter and the citation of C. prolifera is as follows.

Coelogyne prolifera Lindl., Genera and Species of Orchidaceous plants: 40.1835; Folia Orchidacea-Coelogyne: 10 (1854) pro parte (excluding J.D.Hooker's collection from Khasi Hills).

Synonyms: C. flavida N.Wallich ex Lindley, Folia Orchidacea-Coelogyne:10.1854; J.D.Hooker, Flora of British India 5:839.1890; G.King \& R.Pantling in Annals of Royal Botanic Garden Calcutta 8:138, T.191.1898; C. ghatakii T.K.Paul, S.K.Basu \& M.C.Biswas in Journal of Bombay Natural History Society $86: 425$ (1989) Synonym Novum.

Specimen examined: Type - Coelogyne prolifera Wallich s.n., Napalia (Nepal) 1821, Wallich List Number 1956, CAL!, K!); Type - Coelogyne ghatakii, India, Manipur, Imphal valley, 20.04.1988, Ghatak 2213a, CAL!).

2. Cylindrolobus motuoensis X.Z.Jin \& J.D.Ya in Phytokeys 130: 107-113. 2019

While describing this new species from China, the authors have overlooked the species $C$. glandulifera (N.C.Deori \& S.J.Phukan) A.N.Rao which is proved similar in major morphological characters (Table-2) after a critical comparative study based on the Type protologues and illustrations of both the species. Hence, $C$. motuoensis has been reduced to a new synonym of $C$. glandulifera.

Table 2. Similarities between Cylindrolobus motuoensis and C. glandulifera

\begin{tabular}{|c|c|c|}
\hline Character & C. motuoensis & C. glandulifera \\
\hline Roots & pubescent & Pubescent \\
\hline Stem & $18-24 \mathrm{~cm}$ long, 3(2) leaved & About $16 \mathrm{~cm}$ long, 3-4 leaved \\
\hline Leaves & lanceolate, acuminate, $10-13 \mathrm{~cm}$ long & lanceolate, acuminate, about $9 \mathrm{~cm}$ long \\
\hline Inflorescence & $\begin{array}{l}\text { 2-flowered, produced from upper stem } \\
\text { nodes }\end{array}$ & $\begin{array}{l}\text { 2-flowered, borne on near the apical of } \\
\text { the stem }\end{array}$ \\
\hline Floral bracts & Dark red, $7 \mathrm{~mm}$ long & Chest-nut brown, $7 \mathrm{~mm}$ long \\
\hline Flowers & $\begin{array}{l}\text { White, with brown tomentum on sepals } \\
\text { externally }\end{array}$ & White, sepals pubescent externally \\
\hline Sepals & Sepals 9-11 mm long, 5-veined & Sepals about $8 \mathrm{~mm}$ long, 3-4 veined \\
\hline Petals & Petals $10 \mathrm{~mm}$ long, 3-veined & Petals about $8 \mathrm{~mm}$ long, 3 -veined \\
\hline Lip & $\begin{array}{l}\text { 6x3 mm, 3-lobed, 3-keeled on disc } \\
\text { (laterals glabrous, running from base to } \\
\text { middle of midlobe; central keel thickened } \\
\text { with orange papilla, from base to tip of } \\
\text { midlobe); lateral lobes of lip suberect, } \\
\text { subovate, slightly introvert at apex; } \\
\text { midlobe ligulate, thickened and papillose } \\
\text { on margins. }\end{array}$ & $\begin{array}{l}\text { 5x3 mm, 3-lobed, 3-lamellate on disc } \\
\text { (lateral lamellae narrow, clavate, glabrous, } \\
\text { running from base to base of midlobe; } \\
\text { median lamella yellow papillose band } \\
\text { ending into a large hairy cushion beyond } \\
\text { the lateral lamellae); side lobes of lip } \\
\text { erect, rounded; mid lobe with long } \\
\text { clavate hair at base and glandular hair } \\
\text { along the periphery }\end{array}$ \\
\hline
\end{tabular}

Considering the conspecificity, the new citation for Cylindrolobus glandulifera is as follows.

Cylindrolobus glandulifera (Deori et Phukan) A.N.Rao in Bull. Arunachal For. Res.26(1\&2): 103.2010.

Synonyms. Eria glandulifera N.C.Deori \& S. Phukan in J.Orch. Soc. India 2 (1-2): 73- 75, 1989. Cylindrolobus motuoensis X.Z.Jin \& J.D.Ya in Phytokeys 130: 107-113.2019, Synonym novum. 
Specimen examined: Eria glandulifera, Type- India, Meghalaya, Khasi Hills, Mawsmai forest, 19.04.1978, N.C.Deori 71816A, CAL! \& Isotype- N.C.Deori 71816B, ASSAM!; Cylindrolobus motuoensis, Type- China, Xizang Autonomous Region, alt.2000 m, 26.02.2017, J.D.Ya, C.Liu, H.J.He 17HT0073, KUN \& Paratype- X.H.Jin,J.D.Ya, 17HT1088, KUN, Colour illustrations!)

\section{NEW COMBINATIONS:}

\section{Sarcoglyphis parishii (Hook.f.) A.N.Rao, comb.nov.}

Basionym: Sarcanthus parishii J.D.Hooker in Bot. Mag. 86:T.5217.1860.

Other Synonyms: Cleisostoma parishii (J.D.Hooker) Garay in Bot. Mus. Leafl. 23: 173 (1972); Sarcoglyphis manipurensis A. N. Rao, Vik. Kumar \& H. B. Sharma in Nordic Journ. Botany 34(2): 191.2016.

Distribution: India (Manipur) and Myanmar (Moulmaine),

Note: Sarcoglyphis manipurensis A.N.Rao et al. has been found conspecific with Cleisostoma parisbii (Hook.f.) Garay and hence treated as a heterotypic synonym by R.Govaerts (2020). Critical study by the present author with the fresh floral material also confirmed that these two species are conspecific but at the same time revealed that the taxon belongs to the genus Sarcoglyphis Garay and not Cleisostoma Blume due to the special characteristic features like the column which has raised clinandrium, laterally compressed rostellum; anther cap with curved beak; pollinia which are placed on the dorsal side of column and with long curved stipe. Hence, Sarcanthus parishii has been transferred for the first time to the genus Sarcoglyphis.

2. Cleisostomopsis salimii (J.Mathew, T.K.Hrideek, V.B. Sreekumar \& K.Madhusudhanan) A.N.Rao, comb. nov.

Basionym: Seidenfadeniella salimii J.Mathew, T.K.Hrideek, V.B.Sreekumar \& K.Madhusudhanan in Webbia 71: 69 (2016).

Distribution: India: Kerala (Endemic)

Note : R. Rice (2019) has recognised the fact that the genus Seidenfadeniella C.S.Kumar (1994) is congeneric to the genus Cleisostomopsis Seidenfaden (1992) because of the identical characters like terete leaves, racemose inflorescence, 3-lobed lip with tubular spur, aseptate spur with y-shaped front-wall callus, column with 2 dentate lateral auricles, sigmatic surface with a basal process etc. Accordingly, he has transferred two species of Seidenfadeniella viz. S. filiformis (H.G.Reichenbach) Christenson \& P.Ormerod and S. rosea (R.Wight) C.S.Kumar to Cleisostomopsis. While doing so, he has overlooked one more species viz. Seidenfadeniella salimii J.Mathew et al. (2016) which is described as new species from Kerala. Hence, this transfer has been done in the present paper.

\section{LITERATURE CITED}

Das, S.J. \& Jain, S.K. 1980. Orchidaceae: Genus-Coelogyne. Fascicles of Flora of India 5. Botanical Survey of India, Howrah, pp, $1-33$.

Deori, N.C. \& Phukan, S.J. 1988. A new species of Eria from India. Journ. Orchid Soc. India 2(12): $55-57$.

Garay, L.A.1972. On the systematics of the monopodial orchids-1. Bot.Mus.Leafl.Harvard Univ. 23(2): $149-212$.

Govaerts, R. 2020. In WCSP (2020). 'World Checklist of Selected Plant Families. Facilitated by the Royal Botanic Gardens, Kew. Published on the Internet; http:/ /wcsp.science.kew.org/ Retrieved 3 December 2020. 
Hooker, J.D. 1860. Sarcanthus parishii Hook.f. in Bot. Mag. 86: T.5217.

King,G. \& Pantling, R. 1898. The orchids of Sikkim Himalaya. Ann. Roy. Bot.Gard. Calcutta 8: 1 $-342$

Kumar, C.S. \& Manilal, K.S. 1994. A Catalogue of Indian Orchids. Bishen Singh Mahendra Pal Singh, Dehra Dun.

Kumar,V.; Sharma, H.B. \& Rao, A.N. 2016. Sarcoglyphis manipurensis sp. nov. (Orchidaceae) from Manipur, India. Nordic Journal of Botany 34: 191 - 196.

Mathew, J.; Hrideek, T.K.; Sreekumar, V.B. \& Madhusudhanan, K. 2016. Seidenfadeniella salimii (Orchidaceae): a new plant species from South Western Ghats, India. Webbia 71(1): 69 71.

Paul, T.K.; Basu, S.K. \& Biswas, M.C. 1989. A new species of Coelogyne (Orchidaceae) from Manipur, India. J. Bombay Nat. Hist. Soc. 86: 425 - 427.

Pfitzer, E.H. \& Kraenzlin, F. 1907. Coelogyne Lindl. In: H.G.A. Engler (ed.), Das Pflanzenreich 32: 20 - 33. Akademie-Verlag, Berlin.

Rao, A.N. 2010. Orchid flora of Arunachal Pradesh-an update. Bull. Arunachal Forest Research 26(1\&2): $82-110$.

Rice, R. 2019. Photo Intro to: Asian Bulbophyllum, Coelogyne \& Dendrobium Orchids (with floristic observations of Subtribe Coelogyninae). Nature \& Travel Books, pp. 222.

Seidenfaden, G, 1992. The Orchids of Indochina. Opera Botanica 114: 1 - 502.

Ya, J.D.; Jin, X.H. \& Liu, C. 2019. Two new species of Cylindrolobus (Orchidaceae) from the eastern Himalayas. Phytokeys 130: 107 - 113. 